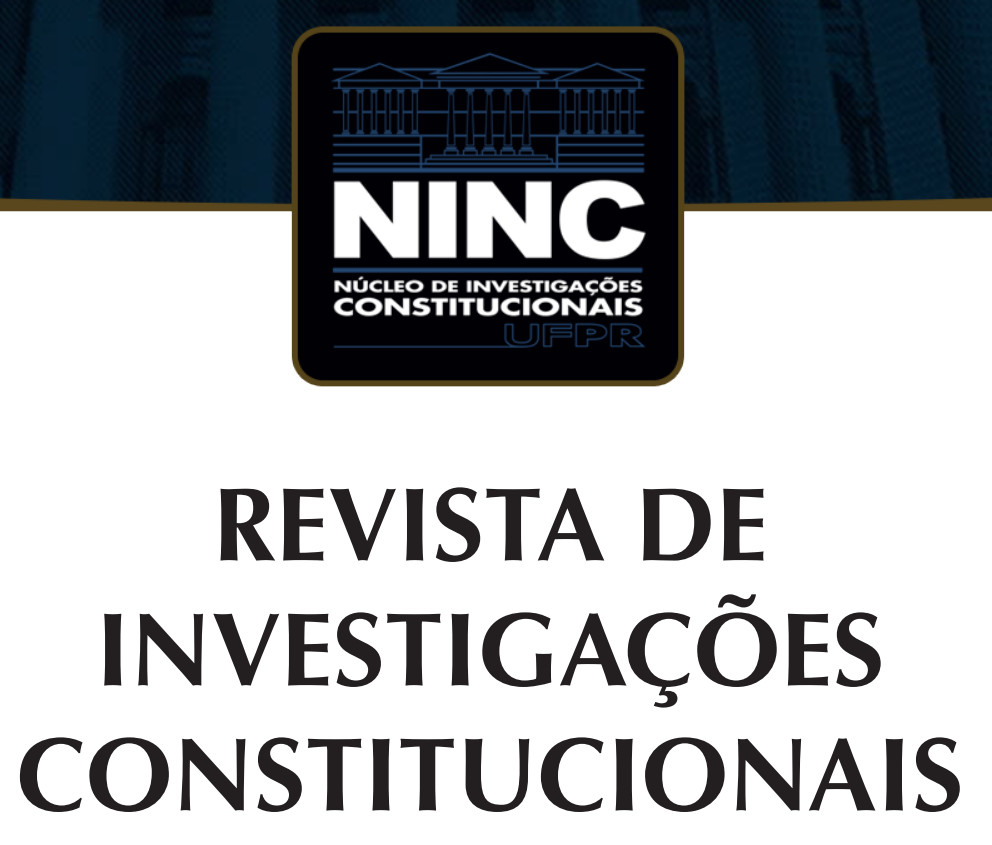

JOURNAL OF CONSTITUTIONAL RESEARCH

vol. 5 | n. 3 | setembro/dezembro 2018 | ISSN 2359-5639 | Periodicidade quadrimestral Curitiba | Núcleo de Investigações Constitucionais da UFPR | www.ninc.com.br 


\title{
Constitutionalizing umbrella-concepts: peace and conflict in the Brazilian Constitution
}

\section{Constitucionalizando conceitos guarda-chuva: paz e conflito na Constituição brasileira}

\author{
ALBA RAMOS ESCOBAR \\ El Colegio de Veracruz (México) \\ albarmse@gmail.com
}

Recebido/Received: 10.08 .2018 / August $10^{\text {th }}, 2018$

Aprovado/Approved: 28.08 .2018 / August $28^{\text {th }}, 2018$

\begin{abstract}
The incorporation of the concept of peace as an umbrella concept within the Brazilian Constitution has generated conceptual problems. This is demonstrated by attempts to understand the scope and limits of peace and conflict established by the Brazilian Constitution. The purpose of this study is to explore the concepts of peace and conflict, in order to clarify the meanings to which the Constitution refers, and to overcome the umbrella concept. For this, articles 4.6 and 4.7 of the Constitution were analyzed, in light of Galtung's theory of peace and conflict and Brazil's foreign policy from 1988 onwards.
\end{abstract}

Keywords: peace; reconceptualization; conflict; Galtung constitutionalization; Brazilian Constitution.

\section{Resumo}

A incorporação do conceito de paz como um conceito genérico dentro da Constituição brasileira gerou problemas conceituais. Isso é demonstrado por tentativas de compreender o alcance e os limites dos conceitos de paz e conflito estabelecidos pela Constituição Brasileira. O objetivo deste estudo é explorar os conceitos de paz e conflito, a fim de esclarecer os significados desses termos referidos pela Constituição e superar a generalidade do conceito. Para tanto, foram analisados os artigos 4.6 e 4.7 da Constituição, à luz da teoria de paz e conflito de Galtung e da política externa brasileira a partir de 1988.

Palavras-chave: paz; reconceitualização; conflito; Galtung; constitucionalização; Constituição Brasileira.

Como citar esse artigo/How to cite this article: ESCOBAR, Alba Ramos. Constitutionalizing umbrella-concepts: peace and conflict in the Brazilian Constitution. Revista de Investigações Constitucionais, Curitiba, vol. 5, n. 3, p. 103-116, set./dez. 2018. DOI: 10.5380/rinc.v5i3.60938.

"M.A. student at El Colegio de Veracruz (Xalapa-Enríquez, México). M.A. in International Studies and B.A. in Law at Universidad Veracruzana (Xalapa-Enríquez, México). E-mail: albarmse@gmail.com. 


\section{CONTENTS}

1. Introduction; 2. Beyond peace as an umbrella concept. Towards a down to earth concept of peace based on the Brazilian foreign policy since 1988; 3. The concept of conflict: Article 4.7 of the Brazilian Constitution; 4. Conflict Resolution; 5. Conflict transformation; 6. Intervention; 7. Conclusion; 8. References.

\section{INTRODUCTION}

Almost since human behavior has been recorded in history, conflicts have existed-sometimes wars, sometimes simple non-violent conflicts; also, since then, ways have been traced to prevent or stop them from happening. The exploration of these topics has always transcended the theoretical scope. The most common approaches to conflict (and peace) throughout history involve literature, movies and, in general, popculture. Conflicts are as familiar as peace - in daily life, in books, in televisions; these are not rare issues to everyone. The reality is that the period which followed the World Wars largely influences how we conceive these topics and even the way people interrelate with each other, or the subjects that are taught at school. The creation of international institutions in which peace is inherent to their existence and theoretical development have impact in our lives, not only, for example, in the prevention of conflict, but also in personal relations or the ways in which the people interact with governments. Despite the signing and ratification of a peace treaty or the inclusion of a State in an international organization that pursues peace being characteristic of commitment to the world, several questions still arise. What happens when a State constitutionalizes these commitments? What does the constitutionalization of peace and conflict resolution really mean, and are these States aware of that meaning? Brazil is one of the States which function in this manner. This paper explores the implications of the concepts of "peace defense" and "pacific resolution of conflicts" established in articles 4.6 and 4.7 respectively of the Constitution of the Federative Republic of Brazil, in light of the theories of peace and conflict developed by Johan Galtung.

It is important, as previously established, to accept that peace and conflict perceptions are generally informal; this is reasonable since people interact with these ideas every day. In daily use of these concepts, one might perceive them as super-concepts or umbrella-concepts that are not clearly defined, such as collective goals, abstract "things" that one may pursue because they have the virtue of being good - whatever that means individually or even collectively. Viewing peace as an umbrella concept has resulted in peace being seen as something unreasonable and imperceptible for research or analysis. However, it is possible and necessary to analyze peace and conflict from a more technical, formal and scientific perspective. In doing so, one can specifically avoid peace becoming an umbrella concept. That is the aim of this article. This article will analyze the aforementioned constitutional articles, specifically the concepts of "peace 
defense" and "pacific resolution of conflicts", in light of conflict theory and will illustrate its implications and meaning in light of specific cases.

\section{BEYOND PEACE AS AN UMBRELLA CONCEPT. TOWARDS A DOWN TO EARTH CONCEPT OF PEACE BASED ON THE BRAZI- LIAN FOREIGN POLICY SINCE 1988}

Transcending the umbrella concept, there are several ways in which peace may be understood. First, there is the old idea, which is referred to as stability and equilibrium in micro (individuals) or macro (countries) situations. Secondly, the 'law and order' idea refers to social order and the observability of the law, even when it is constrained to solely the use of force. Third, there is also the concept of negative peace that refers to the absence of collective organized violence specifically (excluding every other type of violence, like individual violence without a conduct pattern). Lastly, there is the view in which peace represents all that is good - the benefits and merits of being part of the international community, such as cooperation or integration, and sometimes, the resultant absence of violence. ${ }^{1}$ But the question is, which of these meanings best fits the Brazilian Constitution?

Since it cannot be determined exactly what peace means for Brazil by merely regarding the Constitution which seems to utilizes peace as an umbrella-concept, a brief analysis of the shape and design of Brazilian international policy regarding peace and conflict, from 1988 onwards, will be made. It is important to note that this paper will not analyze the whole foreign affairs apparatus. Instead, it will focus on particular issues, that will assist in explaining which of the four ideas of peace best gives a notion of what article 4.6 of the Constitution really means when it says "peace defense".

Brazilian foreign policy can be divided in three overarching aspects: presence, cooperation, and international security. The most noticeable aspect is the prevalence and the active exercise of article 4.4 of the Constitution (which is also an international law principle) regarding no-intervention, and the internally customary ${ }^{2}$ rule with which Brazil has constantly opposed economic sanctions (notably at the United Nations) for issues related to self-determination of the Member States of the International Community. In light of this, Brazil's presence in underdeveloped countries, specifically Portuguese-speaking nations, can also be observed, along with the importance of cooperation to not only Brazil, and the aforementioned countries benefitted by Brazil's cooperation policies, but also the international community as a whole. Although there is even an agency related to international cooperation (Agência Brasileira de Cooperação), emanating from the Ministry of Foreign Affairs, it is important to mention that it is

\footnotetext{
${ }^{1}$ GALTUNG, Johan. A theory of peace. Oslo: Transcend University Press, 1967. p. 12.

${ }^{2}$ In terms of continuous practice of the Brazilian State regarding economic sanctions for issues related to self-determination.
} 
not directly related to the peace agenda; this is evident because of the priority topics, that are agendas themselves, of the Ministry of Foreign Affairs, such as bilateral relations, regional integration, interregional mechanisms, etc.; cooperation and peace and security are separated from each other.

Regarding international security, it is imperative to point out that everything done by Brazil on this issue is in the context of the United Nations ${ }^{3}$ (or this is at least the impression held). In this sense, the important issues of international security are: peacekeeping operations, presence on Lebanon and Haiti, disarmament and arms control, non-proliferation, commitment against the use of chemical weapons, the budget of the United Nations, cooperation with the International Criminal Court, all the issues related to asylum and refuge institutions, and the reform of the United Nations Security Council, which is intended to increase the number of permanent members with veto power.

Considering this, we can conclude that by "defense of peace", article 4.6 of the Brazilian Constitution is actively referring to a combination of stability and equilibrium in micro or macro situations, and negative peace. It also passively refers to the benefits and merits of being part of the international community, given the importance that Brazil places on cooperation, even if Brazil itself does not recognize it, since, as aforementioned, it is not part of the State's peace agenda. It is instead perceived as an independent "project", which in the eyes of Brazil, is limited to cooperation, although in practice it transcends this and contributes to peace.

If, for this case, we conceptualize violence as a biological and physical force, or the effort of causing physical damage to another person, then we may find that a more precise concept of peace may be: the absence of violence and exploitation, with existing equality elements, as well as the search for the absence of negative relations and the search of conditions that facilitate the presence of positive relations. ${ }^{4}$ Both positive and negative relations should be explored separately, even when they are not empirically.

Once the constitutional meaning of "peace" is established, other fundamental concepts, such as positive relations, can be explored: positive relations are a set of what seems to be "superior" intra-national or international values, where the States have an implicit consensus. Galtung has identified ten tentative values of positive relations, which are the presence of cooperation, freedom from fear, freedom from want, economic growth and development, absence of exploitation, equality, justice, freedom of action, pluralism, and dynamism. In general, contradictions cannot be found in positive relations, because even if it is difficult to find all positive relations together at the same time, this is because of structural incompatibility, not logic inconsistence. ${ }^{5}$ Positive

\footnotetext{
${ }^{3}$ The United Nations does not have a monopoly of peace, conflict resolution, transformation or intervention, but normally the States are more secure of themselves contributing to the international community through this international organization.
}

${ }^{4}$ GALTUNG, Johan. A theory of peace. Oslo: Transcend University Press, 1967. p. 14.

${ }^{5}$ GALTUNG, Johan. A theory of peace. Oslo: Transcend University Press, 1967. p. 16. 
relations are an analytic catalogue of problems. The values are useful to highlight certain problems, and, with that, we can maximize and minimize the use of violence.

Now we can reconfigure concepts, including negative peace as the absence of violence; positive peace as the summation of values of positive relations; and national values as the expression of the objectives that States pursue individually.

The analysis above also helps to identify which of the ten tentative values proposed by Galtung are Brazilian intra-national values, i.e. presence of cooperation, freedom from fear, economic growth and development, equality, justice and pluralism.

The importance of understanding this in each case or for each State is to be able to predict how each country would deal with a peace process, either during their own peace process or as an external actor.

Now, a similar case of another State that has positivized peace in its Constitution will be looked at. The case of Japan is particularly interesting because of its own history with war, specifically World War II and the aftermath. The current Constitution ${ }^{6}$ came into force two years after the end of WWII. One of the most important provisions in the whole Constitution and one for which the richest legal discussions have taken place, is Article 9 which establishes the renunciation of war as follows:

(1) Aspiring sincerely to an international peace based on justice and order, the Japanese people forever renounce war as a sovereign right of the nation and the threat or use of force as means of settling international disputes.

(2) In order to accomplish the aim of the preceding paragraph, land, sea, and air forces, as well as other war potential, will never be maintained. The right of belligerency of the state will not be recognized.

As opposed to the Brazilian case and despite this constitutional article being written in negative terms, it gives a clear idea of how Japan views the concept of peace. Article 9 refers to stability and equilibrium in micro and macro situations, social order and observability of the law, and most importantly, it refers actively and explicitly to negative peace as the absence of organized state violence. The discussion can then turn to either the several possible interpretations of the Article 9 which is given by politicians, Courts and academia, or the debate concerning the amendment of this article due to the recent tense relationship with North Korea. Whether this article is only for international peace, although for domestic purposes, it would be unsustainable, can also be examined. However, these debates will not be addressed. Rather, what matters is the explanation of the scope and concept of peace Japan as emanated from the Constitution. Having established the above, we can now clarify that the national values

${ }^{6}$ JAPAN. Constitution of Japan. 3 November 1946. Available at: <http://www.japaneselawtranslation.go.jp/ law/detail_main?re=\&vm=02\&id=174>. Accessed on 14 July 2018. 
based on that brief analysis of Article 9 in light of Japanese foreign affairs. confirm that Galtung's tentative values are also exercised by Japan.

As for Japanese foreign affairs, the country has general agendas ${ }^{7}$ with specific themes within them. For issues addressed in this paper, the relevant agenda is Security/ Peace \& Stability of the International Community, within which the issues are: Crime, Cybersecurity, Disarmament and Non-Proliferation, Peaceful Uses of Nuclear Technology, Human Rights, Humanitarian Assistance, Refugees, International Law and Treaties, Japan and the United Nations, Japan's Security Policy, Maritime Affairs, and Women's Empowerment and Gender Equality. For this case, we are going to focus on Human Rights, Humanitarian Assistance, and Japan and the United Nations. According to the latest National Security Strategy of Japan:

Under the policy of "Proactive Contribution to Peace" based on the principle of international cooperation, Japan will contribute even more proactively in securing peace, stability and prosperity of the international community while achieving its own security as well as peace and stability in the region. ${ }^{8}$

From this, it is clear that Japan's national security strategy does not only refer to security issues from a realist perspective, but it makes cooperation the focus, using it as a direct link towards peace. The approaches that Japan has made to effectuate said strategy include: (1) Strengthening Diplomacy at the United Nation, (2) Strengthening the Rule of Law, (3) Leading International Efforts Towards Disarmament and Non-Proliferation, (4) Promoting International Peace Cooperation, (5) Promoting International Cooperation against International Terrorism. Together, the national security strategy and these five approaches make it clear that Japan, in fact, shares Galtung's tentative values.

\section{THE CONCEPT OF CONFLICT: ARTICLE 4.7 OF THE BRAZILIAN CONSTITUTION}

In order to have a deeper theoretical understanding of Article 4.7, ${ }^{9}$ conflict and conflict resolution must be further investigated. Conflict, on the one hand, always involves contradiction, something that is placed in the middle and impedes something else. ${ }^{10}$ According to Galtung, the elementary formation of conflicts is disputed: two actors, each looking for the same objective; this is followed by a dilemma: when one actor seeks different objectives. A dispute can be observed through the elements that construct it, when the destruction of other actors is observable; however, when

\footnotetext{
${ }^{7}$ JAPAN. Japan's Security / Peace \& Stability of the International Community. 2018. Available at: <http:// www.mofa.go.jp/policy/security/index.html>. Accessed on 14 July 2018.

8 JAPAN. National Security Strategy of Japan. 2018. Retrieved from: <https://www.cas.go.jp/jp/siryou/131217anzenhoshou/pamphlet_en.pdf>.

${ }^{9}$ Pacific resolution of conflicts.

${ }^{10}$ That "something else" is what Galtung call goals.
} 
self-destruction is observed, there is a dilemma. Only when some of this destructive conduct becomes violent, can it be confirmed ${ }^{11}$ that there is a conflict in development. ${ }^{12}$

As previously affirmed, in conflict there is always contradiction. This is because contradiction is formally an element of conflict. Conflict is integrated with attitudes, behaviour and contradiction. ${ }^{13}$ Contradiction is formed when an objective is incompatible with a goal-search system. When a conflict is happening the fundamentals - "attitude" and/or "contradiction" - are latent, while only the "behaviour" is empirically observable. ${ }^{14}$ In order to have a conflict, existing "attitudes" and "behavior" are characterized by tension and/or distention. In both cases, when contradiction is added to the sum, the result is conflict.

The conflicts can be actor conflicts or structural conflicts. In actor conflicts, attitudes and contradictions are happening consciously, while in structural conflicts, they happen unconsciously. Concerning the "behaviour" component, it is always observable in both forms of conflict. ${ }^{15}$

Based on the brief analysis made in the first section, it can be concluded that the concept of conflict in the Brazilian Constitution refers to actor conflict and not structural conflict. In structural conflicts, there is no consciousness of attitudes. In addition, indicators and patterns that show that consciousness is not empirical can be found; the contradictions are inter-systemic, meaning that contradiction is part of the whole system. ${ }^{16}$ The performance of Brazil since 1988 at the international stage, has nothing to do with the characteristics of the structural conflict. An important reason to confirm this claim may be found in article 4.9. ${ }^{17}$ Cooperation as a principle of International Law could make us think that the concept of conflict constitutionally adopted by Brazil is wide and incorporates both structural and actor conflict. However, this is not the case, since intention of article 4.9 has no link with conflict. Instead, it merely concerns the materialization and constitutionalization of a principle of international law.

It is important to explicate the relations found in centre-periphery conflicts. ${ }^{18}$ For an actor to exist in this type of conflict (or, similarly, in horizontal ones), the actor will need space for acting, alternatives to make decisions, the intention of having, as well as pursuing, objectives. These elements comprising the actor-existing problem are impossible to be achieved solely by the periphery actor in centre-periphery conflicts because of the relation of power established from the centre to the periphery.

\footnotetext{
to hurt, harm or destroy another actor.

${ }^{12}$ GALTUNG, Johan. A theory of conflict. Hawaii: University of Hawaii, 1973. p. 59.

${ }^{13}$ Building the conflict triangle.

${ }^{14}$ GALTUNG, Johan. A theory of conflict. Hawaii: University of Hawaii, 1973. p. 31.

${ }^{15}$ GALTUNG, Johan. A theory of conflict. Hawaii: University of Hawaii, 1973. p. 54.

${ }^{16}$ GALTUNG, Johan. A theory of conflict. Hawaii: University of Hawaii, 1973. p. 23-32.

${ }^{17}$ Cooperation among peoples for the progress of humanity

${ }^{18}$ Or vertical conflicts.
}

${ }^{11}$ As it was established previously, violence for this case, refer to physical or verbal one that have the intention 
In this case, and with Brazil being a periphery actor on the international stage, it is interesting to observe the performance of Brazil in the United Nations Security Council post-1988. Brazil has been a member of the Security Council on ten occasions, with five taking place since 1988. During those five periods, Brazil has voted for resolutions almost each instance; however, Brazil has abstained seven times, and voted against one other time. These instances took place regarding: (1) the multinational operation for humanitarian purposes in Rwanda in 1994, where Brazil abstained alongside China, New Zealand, Nigeria and Pakistan; ${ }^{19}$ (2) the authorization of multinational force to restore legitimate President of Haiti Jean-Bertrand Aristide and the removal of the military junta in 1994, where both China and Brazil abstained; ${ }^{20}$ (3) the termination of measures in resolutions 841 (1993), 873 (1993) and 917 (1994) regarding the return of President Jean-Bertrand Aristide to Haiti, in 1994, abstaining along with Russia; ${ }^{21}$ (4) the intervention of a team of the United Nations Mission in Haiti in 1994, abstaining along with Russia;22 (5) the elections in Lebanon and calls for withdrawal of foreign forces in 2004, sharing its abstention with Algeria, China, Pakistan, the Philippines and Russia; ${ }^{23}(6)$ the war in Darfur and the relation with the International Criminal Court in 2005, alongside Algeria, China and United States; ${ }^{24}(7)$ the sanctions on Iran over its nuclear program in 2010, voting against the measures alongside Turkey; ${ }^{25}$ (8) the authorization of the use of a no-fly-zone over Libya, with the explicit task of protecting the civilian population in 2011, where it shared the abstention with China, Russia, Germany and India. ${ }^{26}$

\footnotetext{
${ }^{19}$ UN Security Council, Security Council resolution 929 (1994) [UN Assistance Mission for Rwanda], 22 June 1994, S/RES/929 (1994), available at: <https://documents-dds-ny.un.org/doc/UNDOC/GEN/N94/260/27/PDF/ N9426027.pdf?OpenElement>. Accessed on 14 July 2018.

${ }^{20}$ UN Security Council, Security Council resolution 940 (1994) [UN Mission in Haiti], 31 July 1994, S/RES/940 (1994), available at: <http://unscr.com/en/resolutions/doc/940>. Accessed on 14 July 2018.

${ }^{21}$ UN Security Council, Security Council resolution 944 (1994) [Haiti], 29 September 1994, S/RES/944 (1994), available at: <https://www.sipri.org/sites/default/files/2016-03/944.pdf>. Accessed on 14 July 2018.

${ }^{22}$ UN Security Council, Security Council resolution 964 (1994) [UN Mission in Haiti], 29 November 1994, S/ RES/964 (1994), available at: <http://unscr.com/en/resolutions/doc/964>. Accessed on 14 July 2018.

${ }^{23}$ UN Security Council, Security Council resolution 1559 (2004) [on the political independence and withdrawal of foreign forces from Lebanon], 2 September 2004, S/RES/1559 (2004), available at: <http://www. refworld.org/docid/41516a7e4.html>. Accessed on 14 July 2018.

${ }^{24}$ UN Security Council, Security Council resolution 1593 (2005) [on Violations of International Humanitarian Law and Human Rights Law in Darfur, Sudan], 31 March 2005, S/RES/1593 (2005). Accessed on 14 July 2018.

${ }^{25}$ UN Security Council, Security Council resolution 1929 (2010) [on measures against Iran in connection with its enrichment-related and reprocessing activities, including research and development], 9 June 2010, S/RES/1929 (2010), available at: <http://www.refworld.org/docid/4c1f2eb32.html>. Accessed on 14 July 2018.

${ }^{26}$ UN Security Council, Security Council resolution 1973 (2011) [on the situation in the Libyan Arab Jamahiriya], 17 March 2011, S/RES/1973(2011), available at: <http://www.refworld.org/docid/4d885fc42.html>. Accessed on 14 July 2018.
} 
What can be observed from this is that on several occasions Brazil has used its votes as voice of peripheral States, at a particular stage where the votes have the same wage in-between them ${ }^{27}$, but where only a few States have access.

\section{CONFLICT RESOLUTION}

In the Occident, there is the (mis)conception that conflict resolution is the final state of conflict, and that the solution lasts forever. ${ }^{28}$ Contrary to this notion, conflict resolution is actually a new formation, one which is (1) acceptable for every actor, and (2) sustainable for every actor. ${ }^{29}$ It is also wrongly believed that conflict is officially solved once the elites of each party accept the solutions, ${ }^{30}$ yet this can be problematic. Each actor may sign the conflict finalization bona fide, but this may not be the case in every situation. Signatories can be dishonest. Though, even when being honest, can they really represent and be the voice of all their people, and considering all factors? If everyone agrees, how are they going to sustain the subject? Can they produce less contradictory formations? ${ }^{31}$ Less contradictory formations are acceptable; nevertheless, they must be founded using the appropriate approach. ${ }^{32}$ Otherwise, the outcome will be the constant and almost perpetual result of every conflict resolution: the resurgence of negative behaviour, the influence of old material, and the development of a new or old type of violence and conflict. ${ }^{33}$

Galtung made a strong critique of diplomacy on this subject. He concludes that everything tends to be better and less fragile if diplomats include the elite's fraction of conflict parties interests, but also the people's interests in conflict resolution, and 'not only elite track' as they normally do: "Unfortunately, this type of naiveté is rather widespread, particularly among diplomats, probably because of the feudal nature of their institutions and its function in an inter-system with clearly feudal characteristics"."34

Failings of conflict resolution can be encountered when the mediators are external actors (or "superior" actors) who threaten or pressure the other actors to accept a resolution in the terms that the external actor wants or needs, thereby preventing real agreement. In order to elude this, external actors should be avoided. Instead, the actors may accept mediators that are part of the formation. ${ }^{35}$

\footnotetext{
${ }^{27}$ Even when the weight of the votes between States is the same, is important to highlight that the affirmative vote of nine members required (in all other matters but procedural ones), needs concurring votes of Permanent Members.

${ }^{28}$ GALTUNG, Johan. Peace by peaceful means. Oslo: Prio, 2012. p. 87.

${ }^{29}$ GALTUNG, Johan. Peace by peaceful means. Oslo: Prio, 2012. p. 87.

${ }^{30}$ Because we are used to think conflicts resolution in terms of peace agreements. GALTUNG, Johan. A theory of conflict. Hawaii: University of Hawaii, 1973. p. 54.

${ }^{31}$ GALTUNG, Johan. Peace by peaceful means. Oslo: Prio, 2012. p. 87.

${ }^{32}$ GALTUNG, Johan. Peace by peaceful means. Oslo: Prio, 2012. p. 87.

${ }^{33}$ GALTUNG, Johan. A theory of conflict. Hawaii: University of Hawaii, 1973. p. 37.

${ }^{34}$ GALTUNG, Johan. Peace by peaceful means. Oslo: Prio, 2012. p. 89.

${ }^{35}$ GALTUNG, Johan. Peace by peaceful means. Oslo: Prio, 2012. p. 90.
} 


\section{CONFLICT TRANSFORMATION}

To understand conflict transformation, it must be realized that transformation is permanent; new actions emerge that require responses, and new contradictions may also arise. The best way to deal with this is to construct a stable solution. For the solution to be stable, it needs to have transformation capacity and a method by which it can handle transformation sustainably. It is of utmost importance to understand that the real objective of transformation is the process itself.

What needs to be done in order transform conflicts and transcend formations is to establish conditions: (dis)articulation, ${ }^{36}$ (de)conscientization, ${ }^{37}$ complication or simplification, ${ }^{38}$ (de)polarization, ${ }^{39}$ and (de)escalation. ${ }^{40}$

When the conflict deformation is solved, one realizes that the existence of repressed contradictions is what sometimes make conflicts resurface. ${ }^{41}$

One of the most important conflict transformations in which Brazil actively participated is the Cenepa War regarding the border between Peru and Ecuador. The Protocol of Rio de Janeiro was signed (in 1942) with the intention of ending the conflic$\mathrm{t}^{4}{ }^{42}$ however tensions continued and resurged until $1990 .{ }^{43}$ The re-negotiation finished with other peace accords (the Declaration of Peace of Itamaraty) and officially ended in 1999 with the signing of the Brasilia Act, which in turn also ratified the peace agreements of Protocol of Rio de Janeiro signed in 1942.44

Returning to the theoretical, even after analyzing articles 4.6 and 4.7 of the Brazilian Constitution and concluding that they do not refer to the structural conflicts of Brazil's international relations, structural conflict transformation should be analyzed in order to distinguish it from the other types of conflict transformations.

Structural conflicts include, by definition, structural violence. In this case, the contradiction is inside the verticality of the structure, the repression and exploitation. The vertical elevation is divided between "those above" and "those below". "Those below" may horizontally have two forms of organization that would transform them into actors:

\footnotetext{
${ }^{36}$ Complete or incomplete conflict triangle.

${ }^{37}$ Make attitude or contradiction more or less conscious.

${ }^{38}$ Observe more or less, actors and objectives.

${ }^{39}$ Reduce the formation of conflicts to a more simplistic level.

${ }^{40} \mathrm{Growth}$ and diminution of violence; GALTUNG, Johan. A theory of conflict. Hawaii: University of Hawaii, 1973. p. 110.

${ }^{41}$ GALTUNG, Johan.Peace by peaceful means. Oslo: Prio, 2012. p. 90.

${ }^{42}$ In this case, one can identify what was said before about the external actors, and the possibilities of failure.

${ }^{43}$ This case is a good example of what has been said above about the defects that can be brought about by peace agreements, and therefore, the signing of peace agreements does not guarantee peace per se.

${ }^{44}$ The immediate effect of the agreements was to seek peace, through the withdrawal of troops from the area of confluence, and the establishment of recognized borders by the international community.
} 
conscientization and mobilization. " ${ }^{45}$ "Those above", trying to avoid "those below" from becoming actors, exercise forms of prevention: penetration ${ }^{46}$ and segmentation ${ }^{47}$ for conscientization, ${ }^{48}$ and fragmentation ${ }^{49}$, alongside marginalization for mobilization..$^{50 / 51}$ The steps to overcome the structural violence faced by "those below" are: (1) confrontation through the selection of a topic that encapsulates the conflict in general; (2) struggle without violence to overcome the repression and exploitation; ${ }^{52}$ (3) decoupling, to cut the structural relation between the repressor and the exploiter, which helps to generate positive structures below; deprivation or no cooperation has the objective of constructing autonomy for "those below", and make them less repressible and exploitable; ${ }^{.53}$ and (4) recoupling to generate new and less violent structures, because although, decoupling functions well for its purposes, it is not the long term objective; recoupling has the objective of generating a new horizontal structure, which guarantees human rights instead of repression, equity instead of exploitation, autonomy instead of penetration, integration instead of segmentation, and participation instead of marginalization. ${ }^{54}$

Conflict transformation by complex actors, is sui generis, and so should be the approach taken. In this case, the centre-periphery frameworks will be either bilateral or multilateral. Two of the exact approaches are diachronic, while the other is synchronic. The first diachronic approach generates from the centre with an easy link, whereas the second diachronic approach is produced from the periphery with an easy link, and the synchronic approach is developed with all the links at the same time. ${ }^{55}$

One of the final points that Galtung adds to conflict transformation is that we may think about it as a chain; first we need to simplify, then evade polarization, and finally guide the formation to a higher level of transformation, possibly through intervention.

\section{INTERVENTION}

The final part of the theory is particularly important, due to the common formal conception of what peace empirically means. Ever since peace (as an umbrella-concept) was popularized by the League of Nations and later the United Nations, there has

\footnotetext{
${ }^{45}$ GALTUNG, Johan. Peace by peaceful means. Oslo: Prio, 2012. p. 93.

${ }^{46}$ Conditioning the mind by those above.

${ }^{47}$ Limitation vision of reality of those below.

${ }^{48}$ Separation of each other of those below.

${ }^{49}$ Separation of some from those below from the rest of each other.

${ }^{50}$ GALTUNG, Johan. A theory of conflict. Hawaii: University of Hawaii, 1973. p. 129.

${ }^{51}$ GALTUNG, Johan. Peace by peaceful means. Oslo: Prio, 2012. p. 93.

${ }^{52}$ GALTUNG, Johan. Peace by peaceful means. Oslo: Prio, 2012. p. 93.

${ }^{53}$ GALTUNG, Johan. Peace by peaceful means. Oslo: Prio, 2012. p. 93.

${ }^{54}$ GALTUNG, Johan. Peace by peaceful means. Oslo: Prio, 2012. p. 93.

${ }^{55}$ GALTUNG, Johan. A theory of conflict. Hawaii: University of Hawaii, 1973. p. 110-117.
} 
been a notion that peace is monopolized in practice by international organizations. In this sense, the scope of their actions is limited. We think in terms of wars. Cooperation, for example, is not even included in the meaning of peace.

Considering this, clarifying the need for and methods of intervention is important. First of all, it needs to be understood that intervention exists to stop destruction and suffering. There are three ways of intervention: (1) peacekeeping, which aims at stopping destruction from a behavioral point of view; (2) peacemaking, which is about creating new structures of conflict and transforming attitudes; and (3) peacebuilding to overcome the origin of conflicts. ${ }^{56}$ When identifying the factors which led the conflict, the parties involved in the conflict have to focus on the past, taking a behaviour-oriented approach, as it offers an empirical basis on which responsibility is distributed amongst actors. When a conclusion is drawn, the parties involved in the conflict need to look towards to the future and be aware that presentism makes scrutiny impossible. This stage has nothing to do with abandoning memory and/or truth processes - the information of the actors is indispensable for moral and juridical processes. Instead, it involves the design of a mechanism used to transcend the conflicts. Since systems have memory, what happened in the past will always be relevant. This is also the reason why it was previously established that the conflict transformation process is the objective by and in of itself; the past will not be sufficient to design the future. In practice, we face the challenge of demonstrating that what has happened was not the law of nature. Rather, both actors and participants need to be shown and convinced that the events could have been different and that the future could be different, if a different course is taken, which is separated from the events of the past. ${ }^{57}$

Finally, other precise directives need to be formulated on peacekeeping, peacemaking, and peacebuilding in practice. Firstly, at the peacekeeping stage, ceasefire will be observed and communication will be secured. Secondly, at the peacemaking stage, observations will lay on the changing of attitudes, basically a reprogram. Thirdly, peacebuilding will concern intervention in conflicts and deliberate forms of implementation through awareness. The objective of peacebuilding is the acceptance of a new formula that can define the formation of new structures and new institutions. Peacebuilding tends to be the most difficult part of the peace process due to the risk that it may not be effective if not properly executed.

One of Brazil's main conflict intervention missions took place in Haiti from 2004 to 2017, in which other countries also participated, especially Latin American countries, such as Chile. Initially, the cause that motivated the intervention was the weakness of the State and its risk of becoming a failed State following the coup d'état in 2004. The circumstances surrounding this situation resulted in the United Nations Security Council's

\footnotetext{
${ }^{56}$ GALTUNG, Johan. Peace by peaceful means. Oslo: Prio, 2012. p. 105.

${ }^{57}$ GALTUNG, Johan. A theory of peace. Oslo: Transcend University Press, 1967. p. 74-78
} 
decision to declare that the conditions of Haiti were a threat to international peace and security in the region. The intervention was a joint effort amongst many States, in which Brazil played a critical role. Brazil was entrusted with the maintenance of peace through the establishment of new structures and institutions. The results and even the decision to intervene have been widely questioned and criticized; however, the reality is that the margin of action of the United Nations and the countries that intervened was very limited, given that Haiti was on the way to becoming a failed State. Therefore, the formation of new structures and institutions is not only more complex in these types of cases, but also requires a special design which is different from those that can be given from the perspective of peace. The mission was concluded in 2017; thus, the results are being awaited in order to determine whether or not the intervention, which began in 2004, can be justified and analyzed in more detail. This intervention and the specific mission that Brazil carried out in Haiti have direct relation to the meaning of peace within the Constitution, which is analyzed in the first part of this article, in terms of peacekeeping and security operations, with the objective to observe the absence of violence.

\section{CONCLUSION}

Given this analysis, a series of conclusions can be drawn in two ways - one of a critical approach and one inspired by the aims of this article.

Importantly, the discussion of the concepts of peace and conflict within this article, along with the analysis of Brazil's foreign policy in 1988 and onwards, help us to understand the meaning of article 4.6 and 4.7 of the Brazilian Constitution. In general, the analysis and interpretations of constitutional precepts or constitutional principles - from approaches other than those that law can provide us - enrich both debate and research. In this case, Johan Galtung's theories of peace and conflict are interdisciplinary by nature, which render the findings even more interesting. On the one hand, the Brazilian concept of peace provided for by the Constitution entails a combination of stability and equilibrium in micro or macro situations and negative peace. On the other hand, the concept of peace also passively refers to "the good things and benefits of being part of the international community". Additionally, the concept of conflict which is referenced by the Brazilian Constitution is 'actors conflict'.

Fulfilling this article's aims to explore and analyze certain constitutionalized theoretical concepts, Galtung's theory helps to not only re-conceptualize articles 4.6 and 4.7 of the Brazilian Constitution, but also to analyze, in more detail, its conceptual limits and scope. Despite having analyzed the practicalities, i.e. Brazilian foreign policy, the study of these issues never ceases to be theoretical; however, this article affirms that by making the concepts definitive they can transcend the theoretical plane and have 
practical implications, whether in foreign policy or the courts, hence the large focus on (re)conceptualizing and translating constitutional precepts into their practical worth.

\section{REFERENCES}

GALTUNG, Johan. A theory of conflict. Hawaii: University of Hawaii, 1973.

GALTUNG, Johan. A theory of peace. Oslo: Transcend University Press, 1967.

GALTUNG, Johan. Peace by peaceful means. Oslo: Prio, 2012.

JAPAN. Constitution of Japan. 3 November 1946. Available at: <http://www.japaneselawtranslation.go.jp/law/detail_main?re=\&vm=02\&id=174>. Accessed on 14 July 2018.

JAPAN. Japan's Security / Peace \& Stability of the International Community. 2018. Available at: <http://www.mofa.go.jp/policy/security/index.html>. Accessed on 14 July 2018.

JAPAN. National Security Strategy of Japan. 2018. Available at: <https://www.cas.go.jp/jp/ siryou/131217anzenhoshou/pamphlet_en.pdf>. Accessed on 14 July 2018.

UN Security Council, Security Council resolution 1559 (2004) [on the political independence and withdrawal of foreign forces from Lebanon], 2 September 2004, S/RES/1559 (2004), available at: <http://www.refworld.org/docid/41516a7e4.html>. Accessed on 14 July 2018.

UN Security Council, Security Council resolution 1593 (2005) [on Violations of International Humanitarian Law and Human Rights Law in Darfur, Sudan], 31 March 2005, S/RES/1593 (2005). Accessed on 14 July 2018.

UN Security Council, Security Council resolution 1929 (2010) [on measures against Iran in connection with its enrichment-related and reprocessing activities, including research and development], 9 June 2010, S/RES/1929 (2010), available at: <http://www.refworld.org/docid/4c1f2eb32.html>. Accessed on 14 July 2018.

UN Security Council, Security Council resolution 1973 (2011) [on the situation in the Libyan Arab Jamahiriya], 17 March 2011, S/RES/1973 (2011), available at: <http://www.refworld.org/docid/4d885fc42.html>. Accessed on 14 July 2018.

UN Security Council, Security Council resolution 929 (1994) [UN Assistance Mission for Rwanda], 22 June 1994, S/RES/929 (1994), available at: <https://documents-dds-ny.un.org/doc/UNDOC/GEN/N94/260/27/PDF/N9426027.pdf?OpenElement>. Accessed on 14 July 2018.

UN Security Council, Security Council resolution 940 (1994) [UN Mission in Haiti], 31 July 1994, S/RES/940 (1994), available at: <http://unscr.com/en/resolutions/doc/940>. Accessed on 14 July 2018.

UN Security Council, Security Council resolution 944 (1994) [Haiti], 29 September 1994, S/ RES/944 (1994), available at: <https://www.sipri.org/sites/default/files/2016-03/944.pdf>. Accessed on 14 July 2018.

UN Security Council, Security Council resolution 964 (1994) [UN Mission in Haiti], 29 November 1994, S/RES/964 (1994), available at: <http://unscr.com/en/resolutions/doc/964>. Accessed on 14 July 2018. 